\title{
ПРОГНОЗУВАННЯ ТРАЕКТОРІЇ НАЦІОНАЛЬНОГО ЕКОНОМІЧНОГО РОЗВИТКУ МЕТОДАМИ ГАРМОНІЙНОГО І СПЕКТРАЛЬНОГО АНАЛІЗУ
}

\begin{abstract}
Мета. Поглиблення та удосконалення методичного інструментарію прогнозування поведінки національних економік в контексті підвищення обтрунтованості та аналітичності державних стратегій розвитку національної економічної системи в умовах високої волатильності, відсутності трендостійкості й нестаціонарності динаміки зовнішніх та внутрішніх сочуільно-економічних процесів иляхом імплементації міждисциплінарних методів гармонійного й спектрального аналізу складних динамічних систем природничого походження та їх адаптації специифіці функціонування та розвитку сочіально-економічних систем.
\end{abstract}

Методика Актуалізація місия прогнозування як важливого самостійного етапу в процесі аналітичного оиінювання збалансованості розвитку виконано на основі структурування, розділення на етапи, систематизацї, групування. Процес обтрунтування міждисциплінарного підходу для прогнозування розвитку національної економічної системи здійснено методами аналізу та синтезу, порівняння та практичної апробачї. Встановлення структурних закономірностей економічної динаміки та прогнозування траєкторії розвитку національної економіки виконано методами гармонійного та спектрального аналізу коливних прочесів динамічних систем.

Результати. Сконцентровано увагу на специифічних рисах часових рядів макроекономічної динаміки як основи прогнозування розвитку національних економік, а саме їх короткої тривалості, нестаціонарності, аперіодичності, полігармонійності та їх впливі на формування адекватного методичного забезпечення прогнозування. Обтрунтовано можливість та ефективність використання методів спектрального та гармонійного аналізу коливних процесів розвитку національної економічної системи. Сформовано гармонійну модель траєкторії розвитку економіки Украӥни протягом 1991-2020 рр., яка дозволила проаналізувати коливну складову динаміки макроекономічних індикаторів на основі фактичних даних, які зберігають всю первісну інформацію, щуо вміщує часовий ряд. За допомогою виокремлення економічних циклів, їх амплітудно-частотних характеристик охарактеризована сучасна фаза розвитку української економіки. На основі розробленої моделі економічної динаміки за показником темпів зміни ВВП виконано прогнозування та встановлені короткострокові, середньострокові та довгострокові тенденції розвитку економіки України.

Наукова новизна. Поглиблення теоретично-методичного інструментарію прогнозування тенденцій розвитку національних економік на основі гармонійного та спектрального аналізу дало змогу сформувати структурний підхід до аналізу економічної динаміки в контексті виділення в ї̈ складі вирімальних гармонік та на основі їх характеристик робити висновки про рівень та очікуванні тенденції розвитку національних економічних систем.

Практична значимість. Адаптована та регламентована прочедура гармонійного та спектрального аналізу коливних прочесів сочіально-економічних систем стала підгрунтям для прогнозування рівня темпів та пропориій розвитку національних економічних систем.

Ключові слова: коливні процеси розвитку, прогнозування економічної динаміки, гармонійний та спектральний аналіз, вирімальні гармоніки, економічні ичикли

Вступ. Економічний розвиток $\epsilon$ спрямованим у часі поступальним процесом, який супроводжується хвилеподібною зміною сукупності економічних елементів та їх структурних співвідношень. Оцінювання закономірностей його динаміки має принципово важливий характер. Саме в них проявляються конкретні механізми ринкового економічного розвитку, пов'язані з процесами оновлення товарних запасів, динамікою інвестицій в основний капітал, з інвестиціями в розвиток інфраструктури, зрушеннями в технологічному, соціально-політичному розвитку. Поряд 3 цим, динамічний, важко передбачуваний, нестаціонарний характер тенденцій та мегатрендів сучасності робить актуальним та вимагає пошуку спеціальних підходів та інструментів для правильного прогнозування майбутніх зрушень та переломів в суспільному розвиткові. Поширювані в сучасній практиці державного стратегічного прогнозування та планування розвитку форсайт-методи імітаційного моделювання, SWOT-аналізу, сценаріїв розвитку потребують поглиблення аналітичності, обгрунтованості, прогностичної значимості ї результатів. Враховуючи вищенаведене актуальною сферою вважається імплементація міждисциплінарних методів гармонійного й спектрального аналізу коливних процесів складних динамічних систем в сферу прогнозування тенденцій розвитку національних економік.

$\begin{array}{ccc}\text { Аналіз } & \text { останніх досліджень i } \\ \text { публікацій. } & \text { Проблематика оцінювання }\end{array}$


динаміки розвитку національної економіки охоплює широкий спектр взаємопов'язаних питань та виступає полем наукового пошуку економістів різних часів та поколінь. Вагомий пласт наукових напрацювань зарубіжних вчених, присвячений пошуку причин та факторів довгострокового розвитку, технологічним укладам та динаміці їх розповсюдження серед національних економік стадіальності економічного розвитку сформований роботами Дж. Голдстайна [J. Smith Goldstein], А. Медісона [A. Maddison], Г. Менша [G. Mensh], Дж. Модельські [G. Modelski], У. Ростоу [W. Rostow], М. Хірооки [M. Hirooka].

Сучасний науковий інтерес в контексті забезпечення розвитку національних економічних систем пролягає в сфері аналітичного оцінювання їх динаміки: тобто встановлення іiі закономірностей, їх функціонального опису 3 метою забезпечення підгрунтя для прогнозування та формування на основі його результатів ефективних стратегій розвитку. Цим питанням присвячені праці потужної школи російського довгохвильового циклізму А. Акаєва, С. Глазьєва, К. Зоїдова, А Коротаєва, Г. Куранова, С. Румянцевої, А. Фоміної, С. Циреля, Ю. Яковця та інших.

Стрімко поширюється сфера застосування прикладних інструментів нелінійної динаміки прогнозування тенденцій розвитку на основі динамічного підходу методами фазового, квазициклічного, фрактального, гармонійного та спектрального аналізів. На цьому сконцентровано наукова думка вчених Боташевої Ф.Б., Сергеєвої Л.Н., Винтизенка А.М., Яковенка В.С.

Вагомим внеском в розвиток питань прогнозування та забезпечення сталого й збалансованого розвитку прийнято вважати праці Амоші O.I., Геєця B.M., Гальчинського А.С., Кизима М.О., Мельника Л.Г., Попової О.Ю. та інших. Методологічними аспектами випереджального, соціально-економічного, інклюзивного, проривного, інноваційного розвитку та його безпеки займалися Вишневський О.С., Кравченко С.I., Ляшенко B.I., Харазішвілі Ю.М., Хобта В.М., Ягельска K.Ю. та інші.

Мета статті (постановка завдання). В широкому полі результатів наукових досліджень розвитку національних економічних систем, отримуваних вітчизняними та зарубіжними вченими, питання методів його регулювання, аналітичного оцінювання, стратегічного передбачення залишаються край актуальними на сьогодні. Віддаючи належне накопиченим науковим напрацюванням в сфері прогнозування розвитку національних економік, потребує поглиблення теоретичнометодичний апарат його здійснення в контексті підвищення адекватності, точності, обгрунтованості в умовах волатильного характеру динаміки розвитку національних економік сучасності. Вищезазначене встановлює мету роботи як обгрунтування та визначення перспективної траєкторії розвитку національної економіки міждисциплінарними методами гармонійного та спектрального аналізу.

Виклад основного матеріалу. Важливою частиною аналітичного оцінювання збалансованості розвитку національної економіки, що зумовлює практичну значимість та закінченість його результатів $\epsilon$ етап прогнозування, який постає невід'ємною складовою формування загальної картини про стан і розвиток такого складного об'єкту як національна економіка. Згідно [1, с. 111] «... сучасне прогнозування передбачає науково обгрунтоване судження про можливі стани деякої системи в майбутньому, про альтернативні иляхи та терміни їх здійснення, воно передбачає отримання кількісних оцінок циих станів за допомогою математичних та інструментальних засобів реалізації...».

Так, на рисунку 1 подано місце прогнозування в процесі аналітичного оцінювання розвитку національної економічної системи господарювання та відібрано інструменти його здійснення. Погоджуючись 3 [1-6], сучасні методи прогнозування часових рядів економічної динаміки доцільно згрупувати наступним чином:

методи, засновані на побудові багатофакторних кореляційно-регресійних моделей;

методи авторегресії, що враховують взаємозв'язок членів часового ряду;

методи, засновані на розкладанні часового ряду на компоненти: тренд, сезонні коливання, циклічна компонента i випадкова складова;

методи, що дозволяють врахувати нерівнозначності вихідних даних;

методи прямої інтерполяції, що використовують різні трендові моделі. 


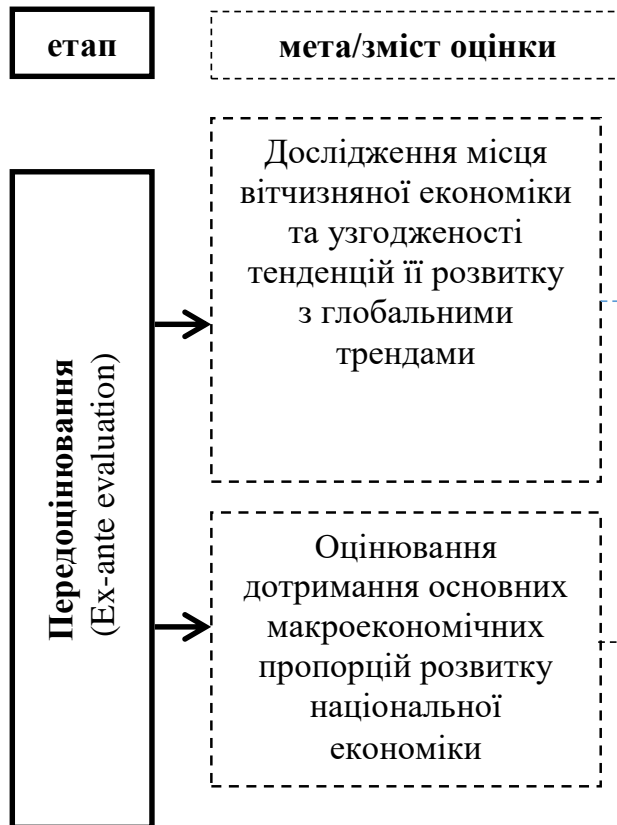

методи/інструменти/показники

Рейтингові методи на основі світових баз даних та відповідних міжнародних індексів розвитку:

Глобальний інноваційний індекс. Індекс проивітання краӥн світу Iнституту Legatum. Індекс глобальної конкурентоспроможності. Індекс людського розвитку. Індекс стійкості

суспільства Світовий індекс щастя. Участь начіональних економік в створенні світового ВВП та добробут їх населення. Пропориії розподілу світового ВВП між національними

Статистичний аналіз макроекономічних індикаторів та показників структурних співвідношень та їх зміни в часі:

Динаміка скоригованих чистих заощаджень. Міжнародна чиста інвестиційна позиція. Оиінка інфляційного розриву в динаміцฺі ВВП України. Ресурсомісткість відтворювальних пропориій украӥнського ВВП. Пропориії внутрішнього розподілу ВВП

України. Пропориії державного/приватного секторів створення ВДВ. Технологічні пропориї в структурі економіки

\begin{tabular}{|c|c|}
\hline 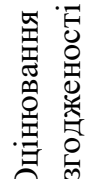 & $\begin{array}{r}\text { Балансовий метод. Мікропідхід до оиінювання } \\
\text { Матричний метод. Фазові портрети розвитку } \\
\text { наиіональної економіки та ї̈ секторів. }\end{array}$ \\
\hline 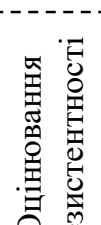 & $\begin{array}{r}\text { Статистичний аналіз: метод п'ятирічної } \\
\text { середньої. Порівняльний аналіз. Історичний } \\
\text { підхід. Матричний метод. Технічний аналіз } \\
\text { динаміки ВВП за показниками швидкості, } \\
\text { прискорення, ривка. }\end{array}$ \\
\hline 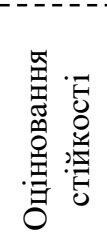 & $\begin{array}{r}\text { Фазовий аналіз динаміки розвитку: побудова } \\
\text { фазових портретів розвитку національної } \\
\text { економіки, графо-аналітична характеристика } \\
\text { режиму ї̈ функціонування, сплайн-моделювання } \\
\text { динаміки макроекономічних показників }\end{array}$ \\
\hline
\end{tabular}

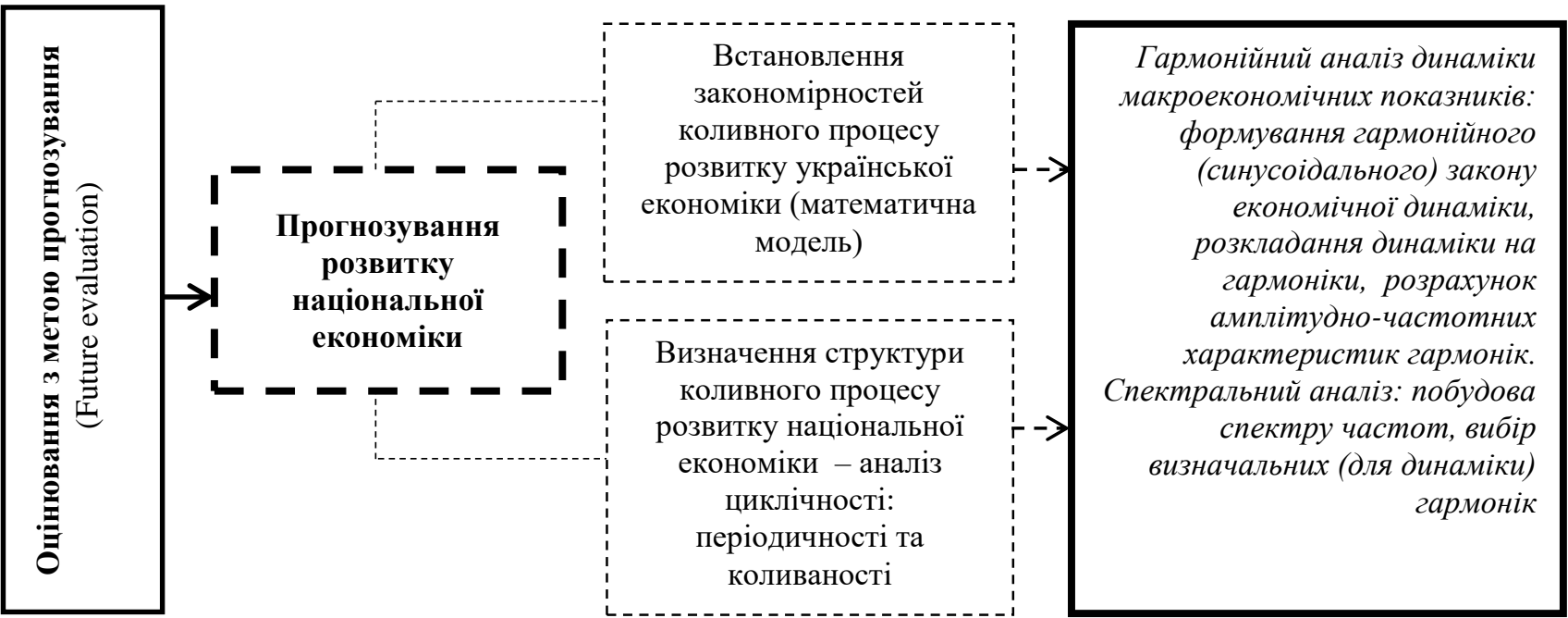

Рис. 1. Етап прогнозування в комплексі методів оцінювання збалансованості розвитку національної економіки Джерело: авторське подання 
Серед вказаних груп найбільш поширеною $\epsilon$ третя група прогнозування макроекономічної динаміки через іiі математичну та статистичну доступність, достатню достовірність й адекватність сучасним умовам господарювання. ІІЇ методи засновані на встановленні структури часового ряду, що описує економічну динаміку, тобто виділенні двох його складових: основної тенденції (тренду) динаміки і ії коливаності та їх співвідношення.

Часовий ряд, як послідовність упорядкованих у часі числових показників, які характеризують рівень стану та зміни явища, що вивчається, виступає основою для оцінювання процесів розвитку економічної системи та іiі збалансованості. Елементами динамічного ряду є перелік хронологічних дат (моментів) або інтервалів часу i конкретні значення відповідних статистичних показників, які називаються рівнями ряду.

Соціально-економічні процеси динамічні, що виявляються сталою зміною рівнів динамічного ряду. Поряд 3 динамічністю їм притаманна інерційність: зберігається механізм формування явищ і характер розвитку (темпи, напрям, коливання). При значній інерційності процесу й незмінності комплексу умов його розвитку правомірно очікувати в майбутньому ті властивості й характер розвитку, які були виявлені в минулому. Діалектична єдність мінливості i сталості, динамічності та інерційності формує характер динаміки, економічних процесів.

Так, «...познание закономерностей изменений во времени - сложная $u$ трудоемкая прочедура исследования, так как любое изучаемое явление формирует множество факторов, действующих в разных направлениях. По характеру непосредственного воздействия эти факторы могут быть разделены на факторы, определяюшие основную тенденцию динамики (рост или снижение уровней) $и$ факторы, вызывающие колебания, которые отклоняют уровни от тенденции то в одном, то в другом направлении...» [7, с. 83].

В контексті мінливої соціальноекономічної ситуації, глобальних ефектів від кризових явищ в окремих секторах окремих національних економік, що викликають значні, важко передбачувані відхилення економічної динаміки, сучасним надбанням статистичного аналізу економічного розвитку вчені вважають методи оцінювання коливаності як самостійної складової часового ряду. Обгрунтуванням цьому виступають наступні положення [7, c. 84]:

коливаність дозволяє висувати гіпотези про причини коливань та формувати шляхи впливу на них;

коливаність $€$ параметричним явищем динаміки, яке можна прогнозувати або розглядати як фактор похибки прогнозу, що значно підвищує його надійність й точність;

результати прогнозування коливаності виступають фундаментом для обгрунтування страхових резервів, необхідних для компенсації негативних наслідків коливань економічної динаміки.

В контексті вищевикладеного систематизовано основні вимірювальні характеристики коливаності, які дозволяють проводити графічний та статистичний іï аналіз.

За допомогою графоаналітичного методу динаміка як технічної, так i соціальноекономічної системи може бути проаналізована за формою коливань (рис.2).

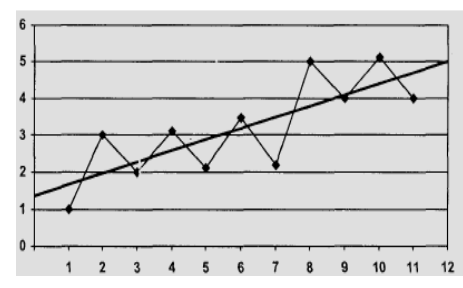

A

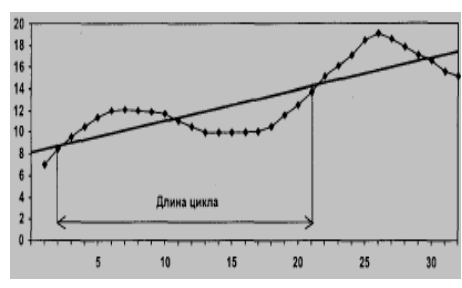

Б

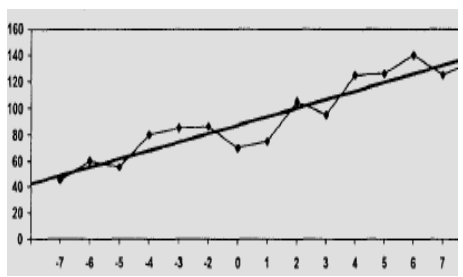

B

Рис. 2. Види коливань економічної динаміки: пилоподібні (А), довгоперіодичні (Б), випадково розподілені у часі (B)

Джерело: систематизовано за [7]

Так, пилоподібні (маятникові) коливання (рис. 2-А) представляють регулярні відхилення від основної тенденції, накопичення відхилень одного знаку не відбувається; достатньо висока 
ступінь прогнозованості. Довгоперіодичні (циклічні, квазіциклічні) коливання (рис. 2-Б) регулярні (квазірегулярні) відхилення від тренду, накопичення відхилень відбувається спочатку одного знаку, потім іншого, періодичність може порушуватися, потрібні великі страхові резерви для ііі компенсації.

Випадково розподілені у часі коливання (рис. 2-В) описуються хаотичною послідовністю відхилень від тренду, коливання слабко прогнозовані, їх взаємопогашення наступають протягом тривалого часу. За допомогою статистичного аналізу вимірюється сила та інтенсивність коливань динаміки.

о показників сили можуть бути віднесені статистичні абсолютні показники коливаності:

амплітуда (розмах) коливань - різниця між максимальним та мінімальним відхиленнями рівнів часового ряду від тренду; середньолінійне відхилення рівнів часового ряду від тренду;

середньоквадратичне відхилення рівнів часового ряду від тренду;

оцінка генерального показника сили коливань

$$
S(t)=\sqrt[2]{\frac{\sum_{i=1}^{n}\left(y_{i}-\widehat{y}_{l}\right)^{2}}{n-p}},
$$

де $y_{i}, \widehat{y}_{l}-$ фактичне та розрахункові значення рівнів часового ряду в і-й момент часу;

$p$ - кількість ступенів свободи в залежності від кількості параметрів тренду; n кількість рівнів часового ряду.

До показників інтенсивності належать статистичні відносні показники коливаності:

коефіцієнт інтенсивності коливань

$$
V(t)=\sqrt[2]{\frac{\sum_{i=1}^{n}\left(y_{i}-\widehat{y}_{\imath}\right)^{2}}{n-p}} \div \bar{y},
$$

де $\overline{\mathrm{y}}$ - середній рівень часового ряду.

\footnotetext{
Систематизовані характеристики $\epsilon$ дієвими як основа для допрогнозного оцінювання динаміки розвитку економічного явища за умов можливості якісного виділення основної тенденції розвитку - тренду та його математичного опису.

Одночасно, об'єктивний аналіз сучасних макроекономічних рядів, які характеризують динаміку розвитку національної економіки, виокремлює такі їх специфічні риси як невелику тривалість через обмеженість у часових рамках існування об'єкту дослідження (30 років української економіки), переважну нестаціонарність (відсутність постійної
}

дисперсії та середньої величини), дискретність (часовий ряд представляє собою моменті дані на відміну від реального процесу безперервного розгортання розвитку економіки), зміну масштабів. Тобто реальний стан економіки вимагає більш гнучких підходів та спеціальних методів оцінювання.

Серед широко застосованих методів до моделювання та оцінки розвитку економічних процесів саме гармонійний та спектральний аналіз має можливість працювати 3 короткими часовими рядами фактичних даних, в яких періодичність динаміки $€$ переважно «зашумленою» присутністю тренду середнього або тренду дисперсії, та давати адекватний для подальшого використання (прогнозування, оцінки структури процесу) результат. До переваг даного методу також відносять можливість будувати закономірності нестаціонарних процесів без початкової оцінки трендів та фільтрації рядів, що $є$ безперечно важливим для рядів економічної динаміки національної економіки України.

В контексті вищенаведених переваг гармонійного аналізу обгрунтовано концептуальний підхід до можливості його використання в рамках дослідження збалансованості розвитку національної економіки.

Зміст підходу полягає у наступному. Поперше, за допомогою гармонійного аналізу встановлюватиметься та математично описуватиметься гармонійна

закономірність коливань динаміки української економіки $з$ метою подальшого По-друге, за допомогою інструментів гармонійного аналізу досліджуватиметься структура економічної динаміки 3 метою встановлення іiі упорядкованості розгортання у описуватиметься гармонійна закономірність коливань динаміки української економіки 3 метою подальшого прогнозування розгортання iï розвитку у часі - періодичності, (циклічності), iii якісних (форма, визначальні гармоніки) та кількісних (тривалість періоду, амплітудночастотні параметри) характеристик.

Отже, надамо ключові визначення теорії гармонійних коливань для можливості правильної інтерпретації застосування гармонійного аналізу з метою оцінювання макроекономічної динаміки розвитку національних економік. Гармонічні коливання як форма динамічних процесів представляють собою коливання, при яких координата, швидкість, прискорення, що характеризують рух динамічної системи, змінюються згідно дії закону синуса або косинуса (формула 3 ). Ïх 
місце в класифікації згідно 3 [5] подано на рисунку 3.

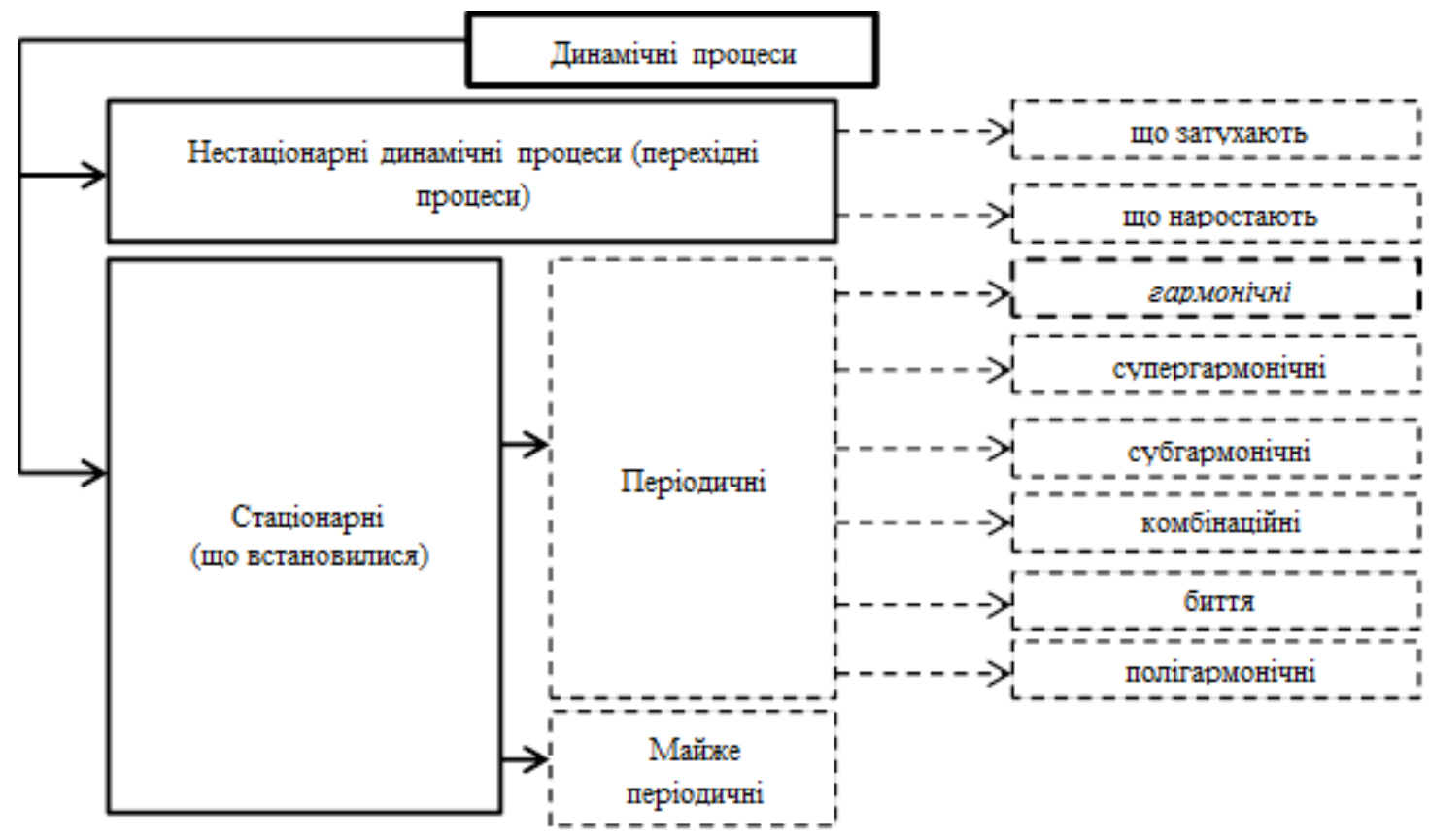

Рис. 3. Класифікація коливань динамічної системи в процесі їі розвитку Джерело: сформовано на основі [3]

Класичне математичне рівняння гармонічного коливання встановлює залежність координати тіла (динамічної системи) від часу (рис. 4).
Графік косинуса в початковий момент часу характеризується максимальним значенням положення динамічної системи - амплітудою A.

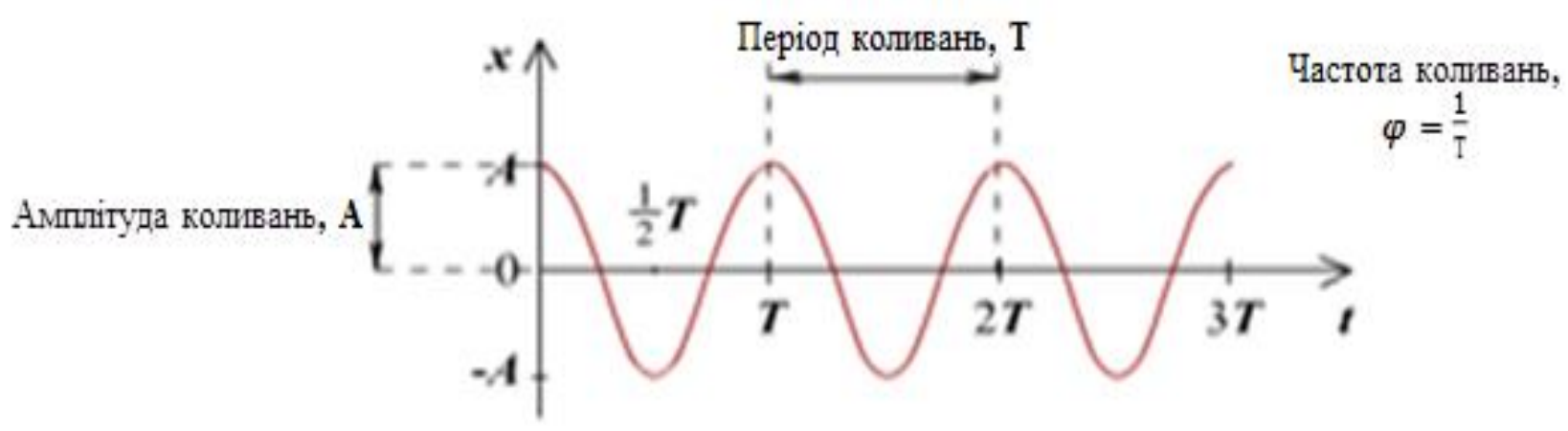

Рис. 4. Косинусоідальний закон коливання динамічної системи Джерело: сформовано за [7]

Графік синуса дозволяє досліджувати коливання 3 положення рівноваги (формула 2).

$$
\begin{aligned}
& x=A \cos \left(\omega t+\varphi_{0}\right) \\
& x=A \sin \left(\omega t+\varphi_{0}\right),
\end{aligned}
$$

де $\quad x-$ координата динамічної системи, яка коливається,

$$
\begin{aligned}
& A\left(x_{0}\right) \text { - амплітуда коливання, } \\
& \omega \text { - циклічна частота, } \\
& t-\text { час, } \\
& \varphi_{0}-\text { початкова фаза }
\end{aligned}
$$

Реальні макроекономічні процеси коливаються за полі гармонічним законом та мають наступну форму (рис 5.) 


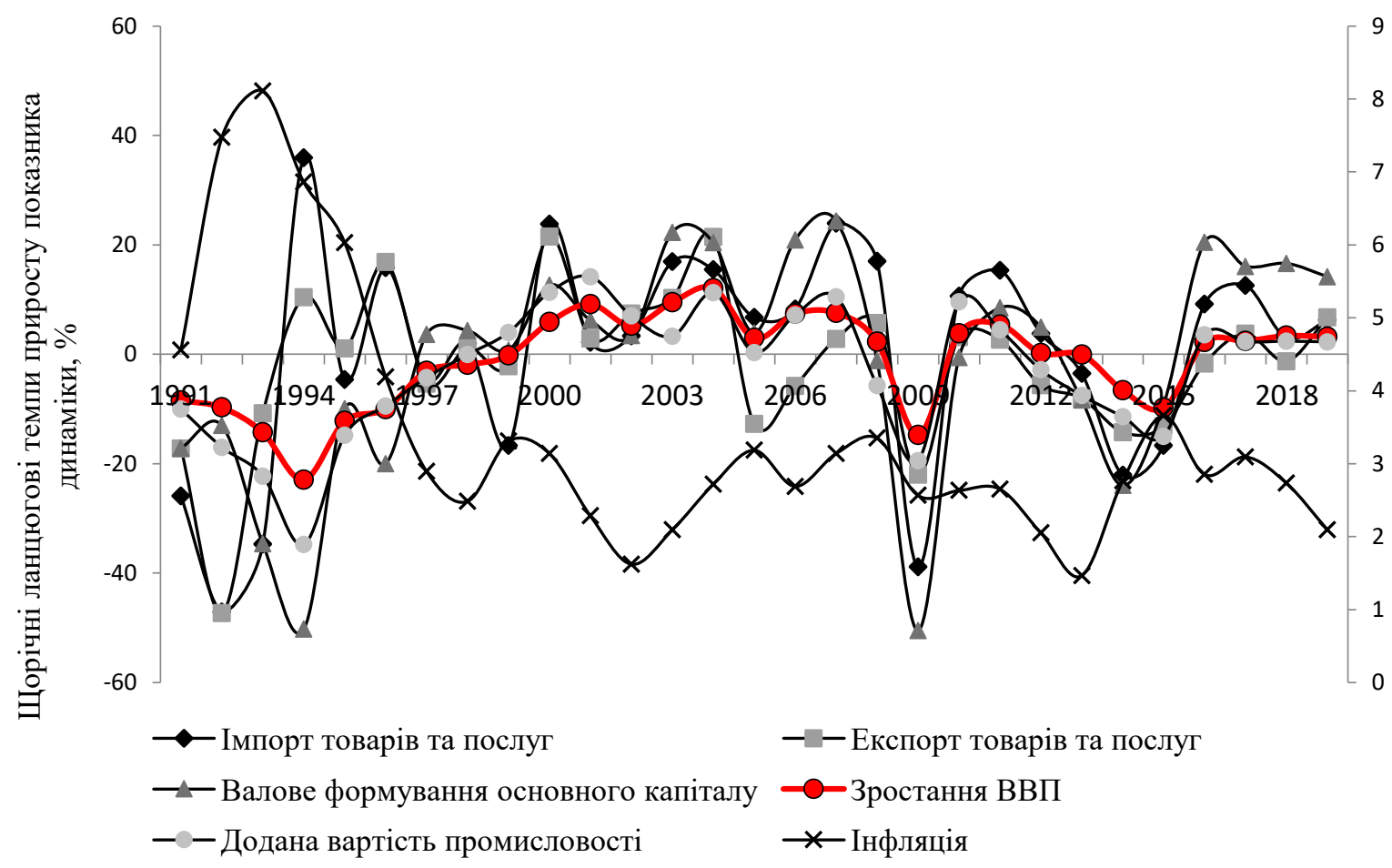

Рис. 5. Хвильова динаміка макроекономічних індикаторів розвитку України за 19912019 рр. Джерело: побудована автором на основі бази даних Світового Банку, 2020

Математична реалізація гармонійного аналізу з урахуванням специфіки економічної динаміки реалізована у наступних етапах.

1. В термінах гармонійного аналізу будь-який фактичний часовий ряд економічної динаміки можна розглядати як сигнал $\mathrm{s}_{\mathrm{r}}$, визначений в дискретні моменти часу $\mathrm{r}(\mathrm{r}=-\mathrm{n}$, $\ldots, 0,1, \ldots, \mathrm{n}-1)$ через рівні інтервали, тривалістю $\Delta$ кожний, довжина запису якого становить T.

Побудована на основі Фур'єперетворення (формули 3-4) дискретна функція $\mathrm{s}_{\mathrm{r}}$ стає наближенням до фактичного ряду динаміки в інтервалі $-\mathrm{T} / 2 \leq \Delta \mathrm{r} \leq \mathrm{T} / 2$. чітна $\mathrm{N}=2 \mathrm{n}$ :

Для сигналу, кількість значень якого $S_{r}=R_{0}+2 \sum R_{m} \cos \left(\frac{2 \pi m}{N} r+\phi_{m}\right)+R_{n} \cos \left(\frac{2 \pi n}{N} r\right)$, де $\mathrm{N}-$ кількість значень детермінованого сигналу $\mathrm{s}_{\mathrm{r}}, \mathrm{N}=\mathrm{T} / \Delta$,

$R_{0} \quad-$ середнє значення рівнів фактичного ряду динаміки (амплітуда нульової гармоніки),

гармоніки,

$$
R_{n} \text { - амплітуда } \mathrm{n} \text {-ної (останньої) }
$$

$m$ - номер гармоніки

$\phi_{m}$ - початкова фаза коливань $m$-ної гармоніки

Для сигналу, кількість значень якого непарна $\mathrm{N}=2 \mathrm{n}-1$ :

$$
S_{r}=R_{0}+2 \sum R_{m} \cos \left(\frac{2 \pi m}{N} r+\phi_{m}\right)
$$

2. Графічне подання (рис.6) Фур'єперетворення дозволить наочно побачити, як формується полігармонічна динаміка. Тобто в термінах гармонічного аналізу побудувати та вимірювати структуру сигналу. 


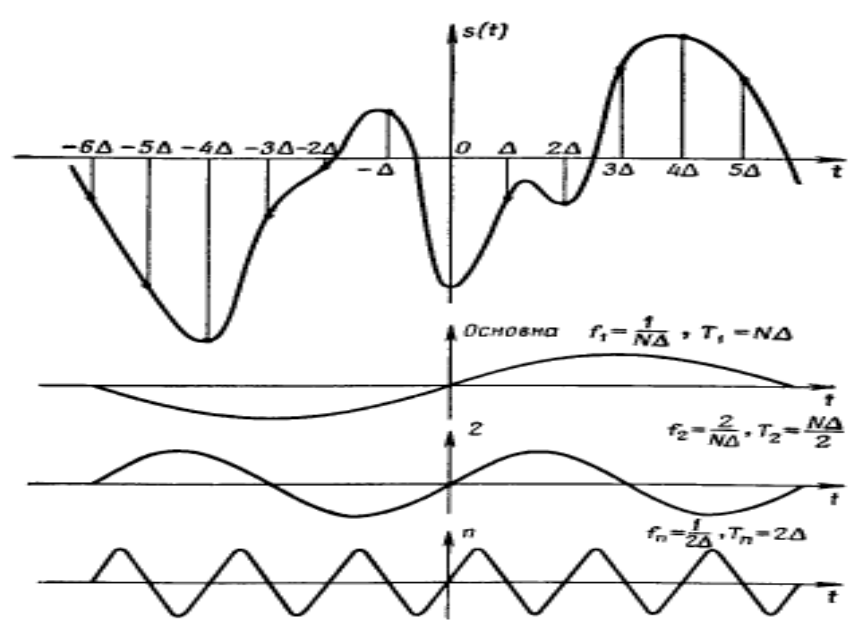

Рис. 6. Гармонійна структура часового ряду динаміки. Джерело: сформовано за [8, с.35]

Розрахунок амплітудно-фазових характеристик надає можливість кількісно оцінювати параметри коливаності динамічного ряду (формули 6-7).

$$
\begin{gathered}
R_{m}=\sqrt{A_{m}^{2}+B_{m}^{2}}, \varphi_{m}=\operatorname{arctg}\left(-\frac{B_{m}}{A_{m}}\right) \\
A_{m}=\frac{1}{N} \sum_{r=-n}^{n-1} s_{r} \cos \left(\frac{2 \pi m}{N} r\right), \quad B_{m}=\frac{1}{N} \sum_{r=-n}^{n-1} s_{r} \sin \left(\frac{2 \pi m}{N} r\right),
\end{gathered}
$$

де $A_{m}, B_{m}-$ коефіцієнти відповідно при косинусі, синусі

3. Для роботи за часовими рядами динаміки різної довжини та форми, сили й інтенсивності коливань обрано програмний функціонал надбудови до MS Excel AtteStat, версія 12.5.0, який використовується вітчизняній практиці при вирішенні поставлених вище завдань. Він ідентифікує обрану складову динаміки заданою кількістю гармонік, чисельно описує іiі амплітудночастотні характеристики.
4. Для вибору найбільш значимих гармонічних коливань, що максимально описуть форму динаміки часового ряду використовується показник середньоквадратичної величини або середньої потужності сигналу. Його обчислення засновано на теоремі Парсеваля, яка стверджує, що середня потужність, що розсіюється сигналом $s_{r}$, може бути розкладена на складові, які надаються кожною гармонікою, що формує цей сигнал (формула 8).

$$
\frac{1}{N} \sum_{r=-n}^{n-1} s_{r}^{2}=R_{0}^{2}+2 \sum_{m=1}^{n-1} R_{m}^{2}+R_{n}^{2}
$$

де $\quad R_{0}^{2}, R_{m}^{2}, R_{n}^{2}$ - квадрати амплітуд коливань відповідно нульової, m-ної, останньої гармонік

5. Формування гармонічного закону коливання динамічного ряду (або його моделі) здійснюється на основі формул 3-4, конкретизованих 3 урахуванням найбільш значимих гармонік, відібраних за показником середньої потужності сигналу. Отримана модель є основою для прогнозування розвитку економічного явища $\mathrm{y}$ часі. Якість прогнозування зумовлюється якістю спектра сигналу, що розраховується як комбінація внеску у \% кожної гармоніки в середню 
потужність сформованого ними сигналу та іï частоти.

Як було сказано вище, економічний розвиток вітчизняної економіки описується динамікою спеціально відібраних індикаторів. Однією 3 таких універсальних й, отже, найбільш поширених характеристик є динаміка ВВП країни, яка, за світовою практикою, представляє собою полігармонійний коливний процес зі складною структурою накладених різних за довжиною хвиль, що відповідають за загальну форму та інтенсивність економічного розвитку.

3 одного боку вона характеризує загальний фазовий стан економіки та розгортання довгохвильового процесу. В той же час в динаміці ВВП можна побачити всю сукупність причинних факторів довгого циклу, які проявляються в коротших за тривалістю коливаннях науково-технічної, фінансової, ресурсної, інфраструктурної сфер економіки. Отже, спираючися на вищенаведене, прогноз розвитку національної економіки формуватиметься на основі косинусоідальної моделі коливної динаміки ВВП України за 1991-2020 роки.

Фактичний ряд динаміки обраного макроекномічного індикатору розвитку представляє собою щорічні ланцюгові темпи зростання ВВП країни, сформовані на основі бази даних Світового банку (табл. 1).

Таблиця 1 - Щорічни темпи зростання ВВП України за 1991-2019 pp, \%

\begin{tabular}{|c|c|c|c|c|c|}
\hline Рік & $\begin{array}{c}\text { ВВП, темп } \\
\text { приросту, \% }\end{array}$ & Рік & $\begin{array}{c}\text { ВВП, темп } \\
\text { приросту, \% }\end{array}$ & Рік & $\begin{array}{c}\text { ВВП, темП } \\
\text { приросту, } \%\end{array}$ \\
\hline 1991 & $-8,4$ & 2001 & 9,2 & 2011 & 5,5 \\
\hline 1992 & $-9,7$ & 2002 & 5,2 & 2012 & 0,2 \\
\hline 1993 & $-14,2$ & 2003 & 9,5 & 2013 & 0,0 \\
\hline 1994 & $-22,9$ & 2004 & 12,1 & 2014 & $-6,6$ \\
\hline 1995 & $-12,2$ & 2005 & 3,0 & 2015 & $-9,8$ \\
\hline 1996 & $-10,0$ & 2006 & 7,4 & 2016 & 2,2 \\
\hline 1997 & $-3,0$ & 2007 & 7,6 & 2017 & 2,5 \\
\hline 1998 & $-1,9$ & 2008 & 2,3 & 2018 & 3,4 \\
\hline 1999 & $-0,2$ & 2009 & $-14,8$ & 2019 & 3,2 \\
\hline 2000 & 5,9 & 2010 & 3,8 & 2020 & $-4,2$ \\
\hline
\end{tabular}

Джерело: складено автором за даними Світового банку, 2021

За економічним сенсом ряд характеризує швидкість і напрямок розгортання розвитку країни протягом 1991-2020 років. Виступаючи універсальним показником результатів створення валової доданої вартості (ВДВ) національних галузей та видів економічної діяльності, динаміка ВВП, як сукупність його темпів зростання та темпів падіння, несе в собі інформацію про узагальнений стан національного господарства та характеристики його трансформації у часі.

За вищевикладеною методикою гармонійного аналізу отримані та зведені в таблицю 2 первісні технічні характеристики часового ряду економічної динаміки ВВП.

Таблиця 2 - Первісні характеристики часового ряду динаміки ВВП за 1991-2020 pp.

\begin{tabular}{|l|c|c|c|}
\hline \multicolumn{1}{|c|}{ Назва характеристики часового ряду } & $\begin{array}{c}\text { Умовне } \\
\text { позначення }\end{array}$ & Значення показника & $\begin{array}{c}\text { Одиниця } \\
\text { виміру }\end{array}$ \\
\hline 1 & 2 & 3 & 4 \\
\hline 1. Безперервний сигнал часового ряду & $S_{t}$ & $\begin{array}{c}\text { Реальна динаміка ВВП } \\
\text { протягом 30-ти років }\end{array}$ & роки \\
\hline 2. Довжина сигналу, період & $\mathrm{T}$ & 30 & роки \\
\hline
\end{tabular}


Продовження таблиці 2

\begin{tabular}{|c|c|c|c|}
\hline 1 & 2 & 3 & 4 \\
\hline 3. Інтервал розбиття сигналу & $\Delta$ & 1 & рік \\
\hline $\begin{array}{l}\text { 4. Кількість значень детермінованого } \\
\text { сигналу }\end{array}$ & $N=\frac{T}{\Delta}$ & 30 & - \\
\hline $\begin{array}{l}\text { 5. Порядковий номер дискретного моменту } \\
\text { часового ряду }\end{array}$ & $\begin{array}{c}r, \\
t=\Delta r\end{array}$ & $\begin{array}{c}r \text { змінюється за цілими } \\
\text { числами, } r:=1, \ldots N \\
r:=r_{1}, r_{2}, \ldots, r_{30}\end{array}$ & - \\
\hline $\begin{array}{l}\text { 6. Детермінований в дискретні моменти часу } \\
\text { сигнал часового ряду }\end{array}$ & $S_{r}$ & $\begin{array}{c}\text { Фактична динаміка ВВП з } \\
1991 \text { до } 2020 \text { року }\end{array}$ & $\%$ \\
\hline $\begin{array}{l}\text { 7. Кількість гармонік часового ряду, } \\
\text { Порядковий номер гармоніки } \\
\end{array}$ & $\begin{array}{c}N / 2 \\
m\end{array}$ & $\begin{array}{c}15 \\
m:=1, \ldots, 15\end{array}$ & - \\
\hline 8. Основна гармоніка & - & $m=1$ & - \\
\hline 9. Вищі гармоніки & & $m=2, \ldots, 15$ & - \\
\hline $\begin{array}{l}\text { 10. Змодельований сигнал дискретного } \\
\text { часового ряду }\end{array}$ & $\widehat{S_{r}}$ & $\begin{array}{c}\text { Змодельована динаміка } \\
\text { ВВП з } 1991 \text { до } 2020 \text { року }\end{array}$ & $\%$ \\
\hline
\end{tabular}
Джерело: сформовано автором

3 метою структурного аналізу динаміки щорічних темпів зміни ВВП України 1991-2020 pp. та здійснення прогнозування розвитку української економіки за встановленими вище етапами (етапи 1 - 5), фактичними даними (табл. 1) та їх первісними технічними характеристиками (табл. 2) 3 використанням математичної надбудови Attestat 12.5.0 здійснено гармонійний аналіз часового ряду. Основні результати необхідні для економічної інтерпретації та подальших розрахунків подані в таблиці 3.

Таблиця 3 - Результати аналізу Фур'є щорічних темпів зміни ВВП України 1991-2020 pp.

\begin{tabular}{|c|c|c|c|c|c|c|c|c|c|c|}
\hline \multicolumn{2}{|c|}{ Гармоніка, m } & \multirow{2}{*}{$\begin{array}{c}\text { Коэф. } \\
\text { COS } \\
\left(\mathrm{A}_{\mathrm{m}}\right)\end{array}$} & \multirow{2}{*}{$\begin{array}{c}\text { Коэф. } \\
\text { SIN } \\
\left(\mathrm{B}_{\mathrm{m}}\right)\end{array}$} & \multirow{2}{*}{$\begin{array}{c}\text { Амплітуда } \\
\text { m-й } \\
\begin{array}{c}\text { гармоніки } \\
\left(\mathrm{R}_{\mathrm{m}}\right)\end{array} \\
1,2\end{array}$} & \multirow{2}{*}{$\begin{array}{c}\text { Фаза m-й } \\
\text { гармоніки } \\
\left(\phi_{m}\right) \\
0\end{array}$} & \multirow{2}{*}{$\begin{array}{c}\begin{array}{c}\text { Середня } \\
\text { потужність } \\
\text { m-й } \\
\text { гармоніки }\end{array} \\
1,3\end{array}$} & \multirow[t]{2}{*}{$\begin{array}{c}\text { Внесок m-й } \\
\text { гармоніки в } \\
\text { середню } \\
\text { потужність, } \\
\% \\
0,5\end{array}$} & \multirow[t]{2}{*}{$\begin{array}{c}\text { Частота } \\
\text { m-й } \\
\text { гармоніки, } \\
\text { період у } \\
\text { рік, }\left(\vartheta_{m}\right) \\
\end{array}$} & \multirow[t]{2}{*}{$\begin{array}{l}\text { Тривалість } \\
\text { циклу т-й } \\
\text { гармоніки, } \\
\text { роки, }\left(T_{m}\right)\end{array}$} & \multirow[t]{2}{*}{$\begin{array}{c}\text { Кількість } \\
\text { циклів за } \\
\text { період }\end{array}$} \\
\hline Середнє & 0 & & & & & & & & & \\
\hline Основна & 1 & $-6,8$ & $-1,9$ & 7,0 & $-16,0$ & 98,6 & 35,4 & 0,0333333 & 30,0 & 1 \\
\hline \multirow{14}{*}{ Вищі } & 2 & 2,7 & $-5,9$ & 6,5 & 65,3 & 83,5 & 30,0 & 0,0666667 & 15,0 & 2 \\
\hline & 3 & 2,2 & $-1,2$ & 2,5 & 28,6 & 13,0 & 4,7 & 0,1 & 10,0 & 3 \\
\hline & 4 & 2,3 & $-1,8$ & 2,9 & 37,1 & 16,8 & 6,1 & 0,1333333 & 7,5 & 4 \\
\hline & 5 & $-1,3$ & $-1,3$ & 1,8 & $-44,2$ & 6,5 & 2,3 & 0,1666667 & 6,0 & 5 \\
\hline & 6 & $-1,5$ & 2,4 & 2,8 & 58,1 & 15,6 & 5,6 & 0,2 & 5,0 & 6 \\
\hline & 7 & 0,5 & 0,2 & 0,6 & $-17,0$ & 0,6 & 0,2 & 0,2333333 & 4,3 & 7 \\
\hline & 8 & $-1,8$ & $-1,3$ & 2,2 & $-35,7$ & 9,4 & 3,4 & 0,2666667 & 3,8 & 8 \\
\hline & 9 & 1,5 & 0,8 & 1,7 & $-28,7$ & 6,1 & 2,2 & 0,3 & 3,3 & 9 \\
\hline & 10 & $-0,5$ & $-2,7$ & 2,7 & $-79,2$ & 15,1 & 5,4 & 0,3333333 & 3,0 & 10 \\
\hline & 11 & $-0,7$ & $-0,6$ & 0,9 & $-39,9$ & 1,6 & 0,6 & 0,3666667 & 2,7 & 11 \\
\hline & 12 & 0,4 & 1,1 & 1,2 & $-70,9$ & 2,9 & 1,0 & 0,4 & 2,5 & 12 \\
\hline & 13 & 0,5 & $-0,2$ & 0,5 & 17,4 & 0,6 & 0,2 & 0,4333333 & 2,3 & 13 \\
\hline & 14 & $-1,1$ & 1,4 & 1,8 & 51,8 & 6,3 & 2,3 & 0,4666667 & 2,1 & 14 \\
\hline & 15 & 0,6 & 0,0 & 0,6 & 0,0 & 0,4 & 0,1 & 0,5 & 2,0 & 15 \\
\hline \multicolumn{2}{|c|}{ Разом } & & & & & 278,4 & 100,0 & & & \\
\hline
\end{tabular}


Так, складну полігармонійну динаміку щорічних темпів зміни ВВП за 1991-2020 рр. (рис. 5) розкладено на 15-ть гармонійних складових, кожна з яких описана в амплітудночастотних характеристиках (табл. 3). За формулою 6 встановлений показник середньої потужності сигналу $S_{r}$ та вклад в нього кожної 3 $m$-гамонік. На основі цього побуновано лінійчастий спектр Фур'є та відібрані найбільш значимі гармоніки, на які, згідно з теоремою Парсеваля, найбільш повно розподіляється середня потужність сигналу (рис.7).

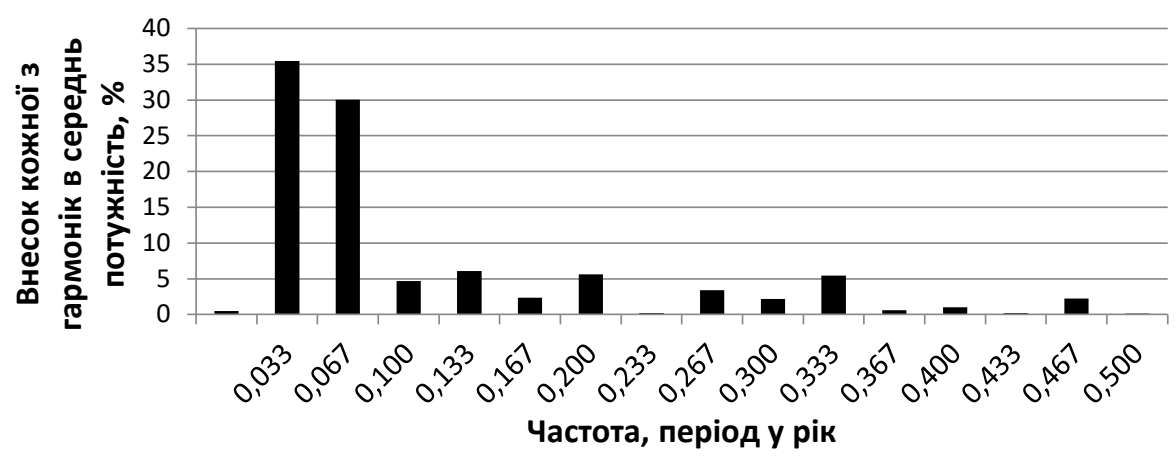

Рис. 7. Спектральний аналіз динаміки ВВП україни за 1991-2020 pp.

Джерело: побудовано автором

Вагоми гармоніками, які найбільш повно описують полігармонійну форму

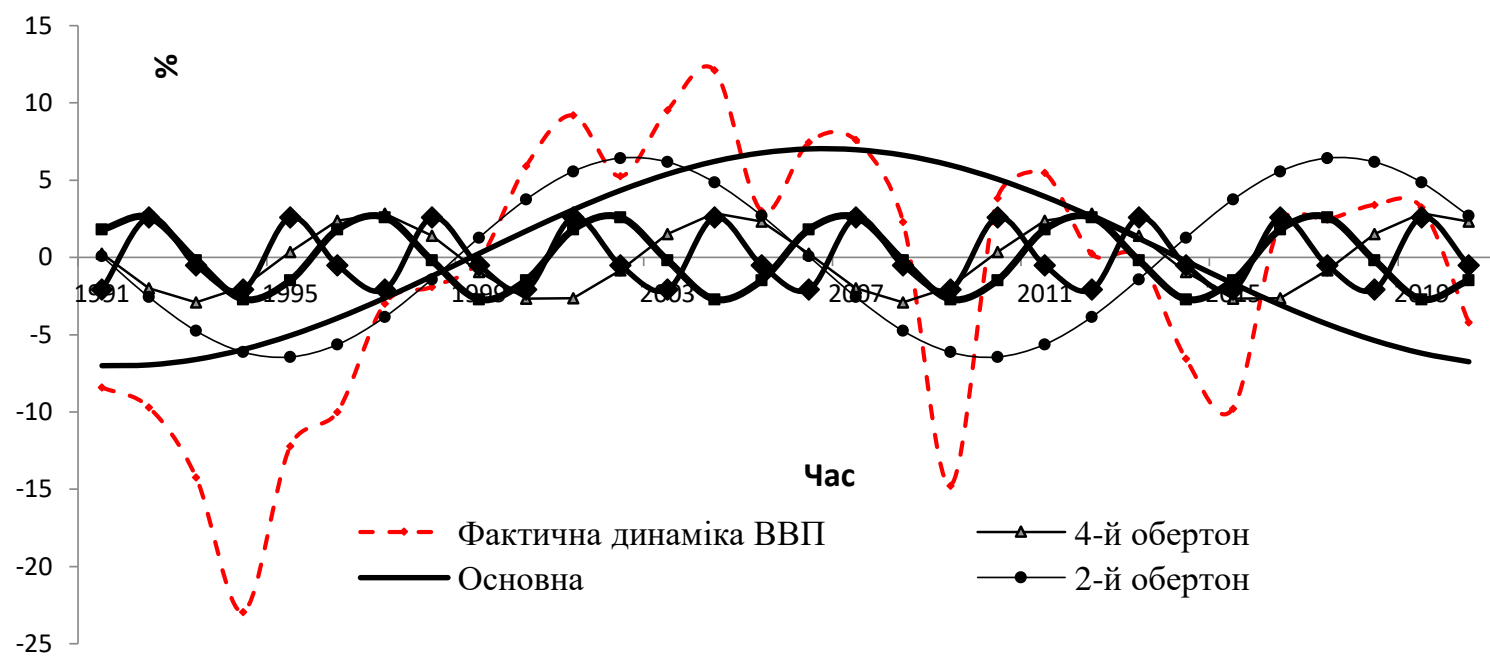

Рис. 8. Вирішальні гармоніки динаміки ВВП України за 1991-2020 pp. Джерело: побудовано автором

Формули $\quad 3-4$ характеризують амплітудно-частотну та фазову інтерпретацію моделі часової дина міки. Для побудови моделі, практично дступної для прогнозування, обраний наступний вид встановлюваної функціональної залежності (формули 9-10).

$$
\widehat{S_{r}}=A_{0}+\sum_{m=1}^{\frac{n}{-}-1} A_{m} \times \cos \left(\frac{2 \pi m}{T}\right) \times r+\sum_{m=1}^{\frac{n}{2}-1} B_{m} \times \sin \left(\frac{2 \pi m}{T}\right) \times r+A_{\frac{n}{2}}
$$




$$
A_{\frac{n}{2}}=\frac{1}{n} \sum_{r=1}^{n} S_{r}(-1)^{r}
$$

На основі вищевиконаних результатів аналітичних розрахунків та статистичних даних розрахована наступна гармонійна закономірність, що описує фактичну динаміку темпів зміни ВВП України за 1991-2020 pp. (формула 11).

$$
\begin{array}{r}
\widehat{S_{r}}=-1,2-6,8 \cos \frac{\pi}{15} r-1,9 \sin \frac{\pi}{15} r+2,7 \cos \frac{2 \pi}{15} r-5,9 \sin \frac{2 \pi}{15} r+2,3 \cos \frac{4 \pi}{15} r-1,8 \sin \frac{4 \pi}{15} r-1,5 \cos \frac{2 \pi}{5} r+ \\
2,4 \sin \frac{2 \pi}{5} r-0,5 \cos \frac{2 \pi}{3} r-2,7 \sin \frac{2 \pi}{3} r
\end{array}
$$

Ступінь наближення змодельованої та фактичної динамік подано на рисунку 9. Графічний аналіз показує достатню ступінь наближення реального та сконструйованого часових рядів.

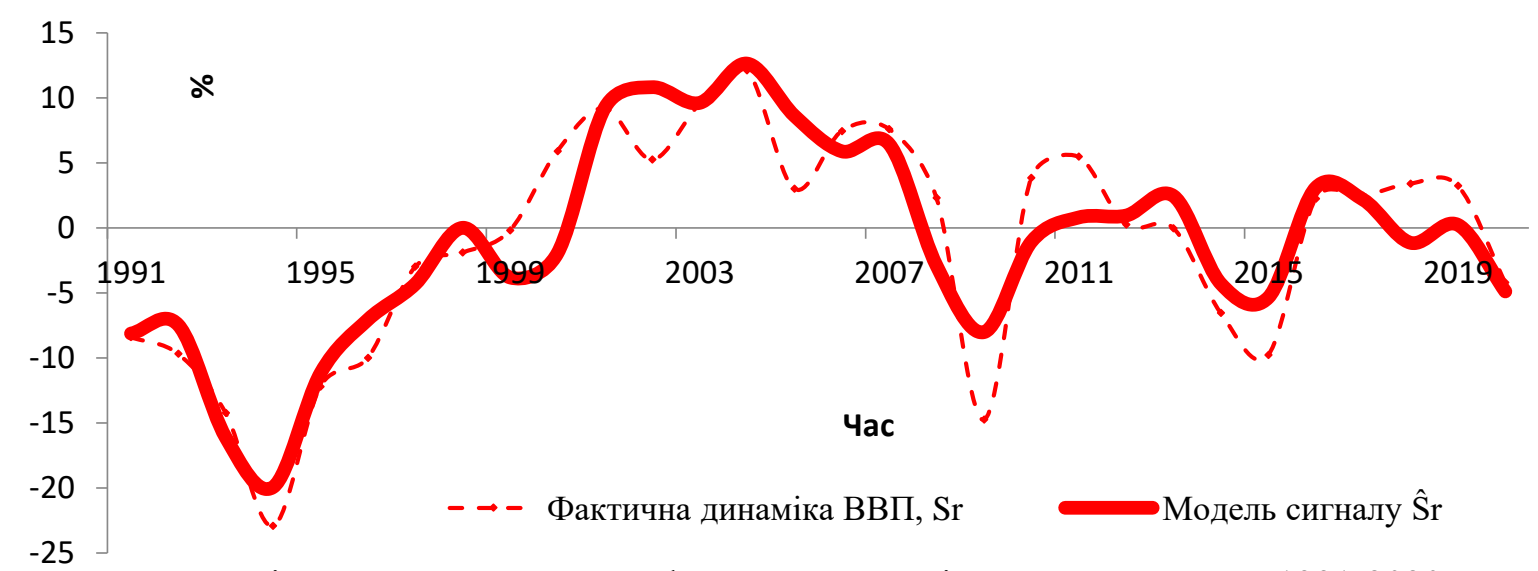

Рис.9. Гармонійний закон коливання фактичної динаміки ВВП україни за 1991-2020 pp. Джерело: побудовано автором

Отже, розрахована за формулами гармонійна закономірність виступає апроксимувальною функцією фактичного динамічного ряду та може бути використана для прогнозування. Виконана перевірка якості моделі за показником середньої арифметичної iii залишків $\left(\overline{e_{r}}\right)$ дала достатні результати. Так, $\overline{e_{r}}=-4,6 \mathrm{E}-13$ (тобто близьке до 0 значення). Показник сумарного вкладу визначальних гармонік в середню потужність сигналу, який склав близько 91,5\% (табл.3), підтверджує високу аппроксимуючу якість сформаованої гармонійної моделі та іiі придатність для прогнозування. Отже результати середньорічного (5-ть років) прогнозу наведені у таблиці 4. Прогнозування виконано методом перспективної екстраполяції, можливість застосування якого зумовлене високою якістю моделі, іiі економічним змістом.

Таблиця 4 - Прогнозна динаміка темпів економічного розвитку української економіки на 2021-2025 p.

\begin{tabular}{|c|c|c|}
\hline Номер періоду & Роки & Прогнозна динаміка ВВП, \% \\
\hline 31 & 2021 & $-8,1$ \\
\hline 32 & 2022 & $-7,5$ \\
\hline 33 & 2023 & $-16,1$ \\
\hline 34 & 2024 & $-19,9$ \\
\hline 35 & 2025 & $-11,2$ \\
\hline
\end{tabular}


Структурний аналіз фактичної динаміки за допомогою гармонійних складових дозволив встановити наступні закономірності. Кожна вирішальна (тобто відібрана згідно з їі вкладом у середню потужність сигналу) гармоніка обраного економічного індикатора розвитку, динаміка якого оцінюється, несе в собі конкретні технічні характеристики: характерну саме для неї амплітуду, частоту коливань, тобто кількість повторень циклу гармоніки за весь період аналізу (наприклад, за 1991-2020рр.), тривалість. Принципова структура циклу будьякої гармоніки сладається 3 двох фаз тривалістю 1/2 загальної довжини циклу: фази зростання та фази падіння. Цикл кожної гармоніки за власною природою $\epsilon$ повторюваністю певних закономірностей за визначений період $\mathrm{y}$ часі (протягом аналізованого періоду), які визначаються характеристиками відповідної гармоніки та специфікою економічного процесу. Тобто, в залежності від того, в якій фазі починався циклічний рух (рівень економічного показника зростав або знижувався), в тій фазі він закінчиться наприкінці загального періоду аналізу економічної динаміки. Спираючись на цей принцип, вирішальні гармоніки, що характеризують темпи зміни ВВП України протягом 1991-2020 рр., розділені на спадні (які закінчуються фазою падіння) (рис. 10) висхідні (які закінчуютья фазою зростання) (рис. 11).

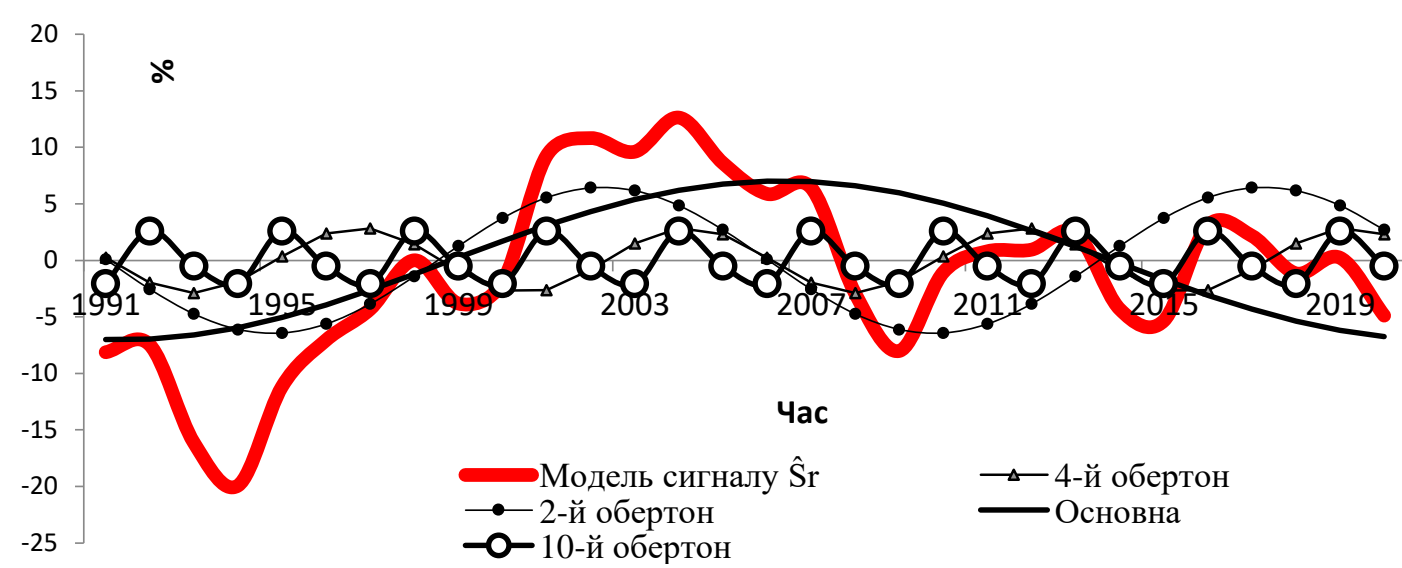

Рис. 10. Спадні визначальні гармоніки та модель динамічного ряду Джерело: побудовано автором

Графічний аналіз наведеного ілюстративного матеріалу встановлює, що 43 5-ти вирішальних гармонік досліджуваної динаміки $€$ спадними. Це свідчить про наявність деструктивних тенденцій, що $\epsilon$ характерними для загального коливного процесу, які зберігуться в майбутньому. Підтвердженням цього став здійснений прогноз 3 його відємними темпами зміни ВВП (табл.4).

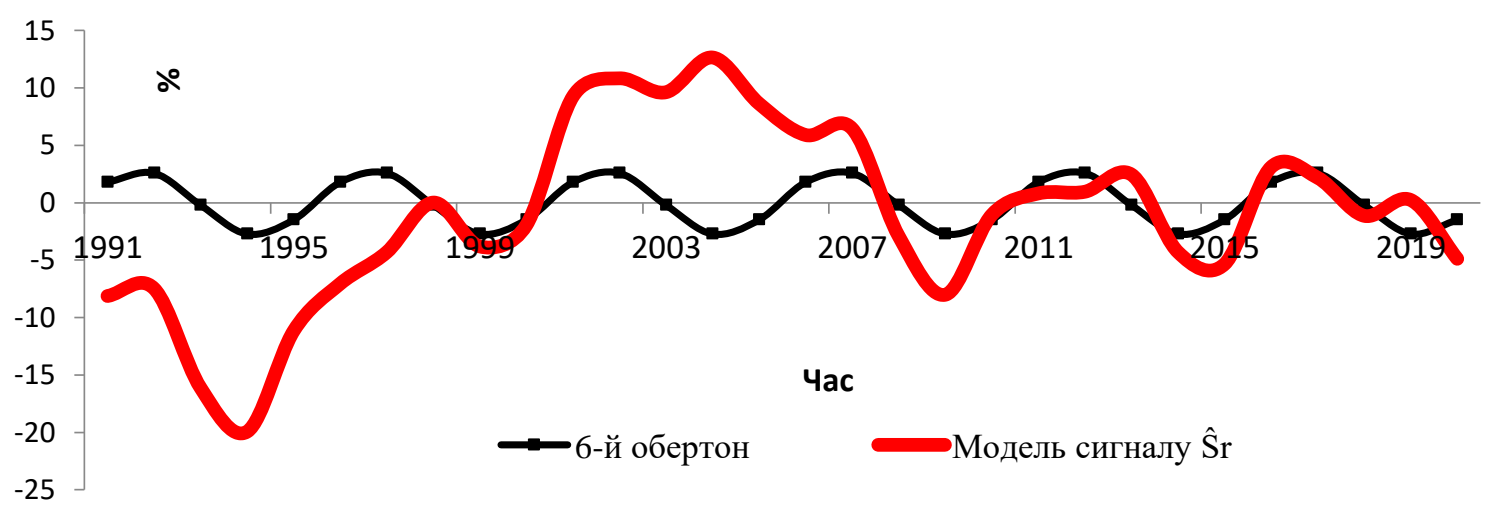

Рис. 11. Висхідні визначальні гармоніки та модель динамічного ряду Джерело: побудовано автором 
Аналізуючі структуру динаміки економічного розвитку України, слід відмітити наявність вирішальних гармонік високих порядків. До них відносять четверту, шосту, десяту гармоніки 3 тривалістю циклу відповідно 7,5, 5, 3 роки.Тобто вони зумовлюють високу частоту коливань динаміки, волатильний характер процесу створення основного доходу країни внутрішнього валового продукту. Отже, на основі гармонійного аналізу та перспективної екстраполяції визначений спадний характер тенденції траєкторії розвитку української економіки. Виконаний середньостроковий прогноз зафіксував її пятирічну тривалість.

Визначені вирішальними гармоніками цикли в динамиці ВВП України довжиною 30, $15,7,5,5$ та три роки зіставлено 3 періодичністю класичних економічних циклів Кітчина [Joseph Kitchin] (3-4 роки), Жугляра [Juglar Clément] (7-11 років), Кузнеця [Kuznets Simon] (15-25 років), Кондратьєва (45-50 років). Встановлено, що динаміка розвитку національної економіки за 1991-2020 pp. підпорядкована довгостроковому циклічному процесу, характерному для коливань, пов'язаних 3 демографічними, інфраструктурними, інвестиційними процесами в економічній системі країни - тобто циклами Кузнеця (рис 12.).

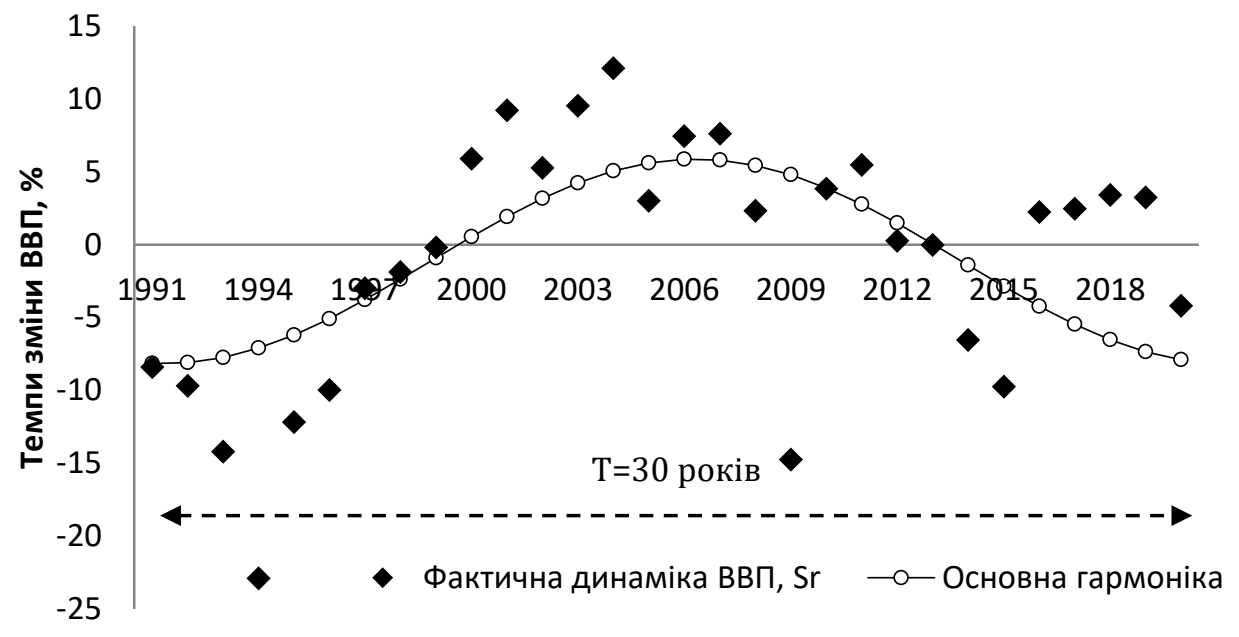

Рис. 12. Цикл Кузнеця в економічній динаміці України. Джерело: побудовано автором

Періодична функція, що описує дане явище та апроксимує фактичну динаміку економічного розвитку України, є основною (першою) гармонікою досліджуваного коливного процесу, математично представлена наступною формулою 12.

$$
\widehat{S_{r}}=-1,2-6,8 \cos \frac{\pi}{15} r-1,9 \sin \frac{\pi}{15} r
$$

Виходячи 3 встановлюваної закономірності, в 2020 році українська економіка знаходиться у спадній фазі циклу Кузнеця, початок якої датується 2008-2009 роками. Згідно виконаному прогнозу іiі завершення очікується в 2023 році від'ємними темпами зміни ВВП на рівні $7,8 \%$. Висхідна тенденція (підфаза пожвавлення) намітиться 32024 до 2029 року та характеризуватиметься уповільненням темпів падіння економіки 3 -
$7,1 \%$ до $-0,9 \%$. Наступна підфаза прискореного зростання висхідної хвилі тридцятирічного циклу Кузнеця очікується в 2030 році з позитивними темпами зміни ВВП на рівні $0,5 \%$. Точність прогнозу обгрунтована якістю прогнозної моделі (формула 11), що вимірюється нульовим середнім рівнем залишків та становить $\hat{\bar{e}}=$ $-2,22 \mathrm{E}-16$. Слід зазначити, що на інтенсивність економічного спаду та 
тривалість спадної тенденції протягом довгострокового циклу Кузнеця. впливає синфазний рух економіки зі спадними частинами циклів Кітчина (визначеного 10тою гармонікою, рис. 10) та Жугляра (визначеного 2, 4 гармоніками, рис. 10).

Обговорення результатів. Отримані результати дослідження дозволяють стверджувати про придатність та продуктивність застосування міждисциплінарних методів гармонійного та спектрального аналізу для прогнозування динаміки розвитку національної економічної системи. Встановлювані даними методами гармонійні закономірності дозволяють структурувати економічну динаміку, виокремлювати піi значимі циклічні компоненти, які пояснюють коливні процеси зміни макроекономічних індикаторів розвитку. Винайдені циклічні коливання за амплітудно-частотними i фазовими характеристиками співвідносяться 3 класичними економічними циклами, тобто стають підгрунтям для змістовного економічного аналізу. Достатньо висока точність отримуваних прогнозних даних створює можливість розробки науково обгрунтованої стратегії розвитку країни. До перспектив дослідження віднесена необхідність поглиблення запропонованого структурного аналізу економічної динаміки за допомогою гармонійних складових іiї руху 3 метою визначення ступеню іiі збалансованості. Також перспективним напрямком в контексті регулювання розвитку та встановлення причиннонаслідкових факторів його динаміки вважається гармонійний аналіз багатомірних часових рядів економічної динаміки, створених на основі класичних моделей економічного зростання, інших

\section{Список літератури}

1. Тебуева Ф.Б., ВПерепелица.А., Кабиняков М.Ю. Декомпозиция и прогнозирование временных рядов с долговременными корреляциями. Известия ЮФУ. Технические науки. 2013. № 1 (138). C. 111-120.

2. Иващенко А.Б. Традиционные и современные подходы в прогнозировании временных рядов. Наукові праиі донецького національного технічного університету: багатофакторних моделей.

Висновок. Отже, математичний інструментарій гармонійного та спектрального аналізу, застосовуваний для дослідження функціонування певного класу складних динамічних систем, для яких характерними $\epsilon$ коливні процеси, апробовано для оцінювання стану та прогнозування траєкторії розвитку національної економіки. Даний методичний апарат дозволив враховувати іiі нестаціонарну, волатильну поведінку, складну полігармонійну динаміку, характерну для сучасних економічних систем, коли коливні процеси ускладнюють процес встановлення та достовірного описання тренду розвитку. В роботі сформовано та узгоджено зі специфікою функціонування національних економічних систем алгоритм здійснення гармонійного аналізу. За показником темпів зміни внутрішнього валового продукту встановлені вирішальні гармоніки та їх амплітудно-частотні й фазові параметри, що характеризують розвиток української економіки з 1991 до 2020 року. Це дозволило сформувати функціональну залежність, тобто апроксимувальну функцію, яка $з$ достатньою точністю описала коливні процеси економічного розвитку української економіки за вказаний період часу. Виконана процедура прогнозування встановила короткострокові, середньострокові довгострокові очікувані траєкторії розвитку економіки України. За допомогою гармонійного аналізу в динаміці економічного розвитку України ідентифіковані класичні цикли Кузнеця, Жугляра, Кітчина, описані ї характеристики, та вплив на характер стану та перспективи розвитку економіки країни.

Серія: «Проблеми моделювання та автоматизації проектування». 2012. № 1 (10)2(11), C. $156-175$

3. Петров Л.Ф. Методы динамического анализа экономики. Москва: Инфра-М, 2010. $240 \mathrm{c}$.

4. Бокс Дж. Анализ временных рядов: прогноз и управление. Москва: Мир, 1974. Т. $1.403 \mathrm{c}$.

5. Кендалл M. Многомерный статистический анализ и временные ряды. Москва: «Наука», 1976. 737c. 
6. Кильдишев Г.С. Анализ временных рядов и прогнозирование Москва: Статистика, 1973. 113c.

7. Афанасьев В.Н., Юзбашев М.М. Анализ временных рядов и прогнозирование. Москва: Финансы и статистика, 2001. 228 с.

8. Дженкинс Г. Спектральный анализ и его приложения. Москва: Мир, 1971. Т. 1. 317 c.

\section{References}

1. Tebuyeva F.B., Perepelitsa V.A., Kabinyakov M.YU. Dekompozitsiya i prognozirovaniye vremennykh ryadov $\mathrm{s}$ dolgovremennymi korrelyatsiyami. Izvestiya YUFU. Tekhnicheskiye nauki. 2013. № 1 (138). S. $111-120$

2. Ivashchenko A.B. Traditsionnyye i sovremennyye podkhody $\mathrm{V}$ prognozirovanii vremennykh ryadov. Naukoví pratsí donets'kogo natsíonal'nogo tekhníchnogo uníversitetu: Seríya: «Problemi modelyuvannya ta avtomatizatsií proyektuvannya». 2012. № 1 (10)-2(11), S. 156175

3. Petrov L.F. Metody dinamicheskogo analiza ekonomiki. Moskva: Infra-M, 2010. 240 s.

4. Boks Dzh. Analiz vremennykh ryadov: prognoz i upravleniye. Moskva: Mir, 1974. T. 1. $403 \mathrm{~s}$.

5. Kendall M. Mnogomernyy statisticheskiy analiz i vremennyye ryady. Moskva: «Nauka», 1976. 737s.

6. Kil'dishev G.S. Analiz vremennykh ryadov i prognozirovaniye Moskva: Statistika, 1973. 113s.

7. Afanas'yev V.N., YUzbashev M.M. Analiz vremennykh ryadov i prognozirovaniye. Moskva: Finansy i statistika, 2001. 228 s.

8. Dzhenkins G. Spektral'nyy analiz i yego prilozheniya. Moskva: Mir, 1971. T. 1. 317 s.

\section{Надійшла до редакиії 02.12.2019p.}

Кладченко Ірина Сергіївна - асистент кафедри економіки підприємства, ДВНЗ "Донецький національний технічний університет", E-mail: iryna.kladchenko@donntu.edu.ua

\section{FORECASTING OF NATIONAL ECONOMIC DEVELOPMENT TRAJECTORY BY METHODS OF HARMONIC AND SPECTRAL ANALYSIS}

Improving of the methodological tools for the national economies behavior's forecasting in the context of increasing the validity and analytical characteristics of state economic strategies in conditions of high volatility, lack of trend stability and non-stationary dynamics of external and internal socio-economic processes by implementing interdisciplinary methods of Fourier analysis and their adaptation to the specifics of the socio-economic systems' functioning and development. Methodology. The forecasting's targeting as an important independent stage in the process of analytical assessment of the balance of development is performed on the basis of structuring, division into stages, systematization, and grouping. Justification of the interdisciplinary approach for forecasting of national economic system's development is carried out by methods of analysis and synthesis, comparison and practical testing. Establishment of the economic dynamics' structural regularities and forecasting of a trajectory of national economy development are executed by harmonic and spectral analysis of the dynamic systems' fluctuating processes. The results. The paper's attention is focused on the specific features of macroeconomic dynamics' time series as a basis for the forecasting of national economies development, namely their short duration, non-stationary, aperiodic, polyharmonic and their impact on the formation of adequate methodological support for forecasting. The possibility and efficiency of spectral and harmonic methods using for analysis oscillating processes of national economic system's development are substantiated. A harmonic model of Ukraine's economic development's trajectory during 1991-2020 is formed, which allowed to analyze the fluctuating component of the macroeconomic indicators' dynamics on the basis of actual data that included all the initial information contained in the time series. By distinguishing economic cycles, their amplitudefrequency characteristics, the current phase of Ukrainian economy's development is characterized. On the basis of the economic dynamics' model, being used the indicator of annual GDP growth, forecasting is executed and short-term, average-term and long-term tendencies Ukraine's economy's development are established. Scientific novelty. The extending of theoretical and methodological tools for forecasting of main trends in national economies, based on harmonic and spectral analysis, is allowed to form a structural approach to the analysis of economic dynamics in the context of selection of its decisive harmonics and basing on their characteristics to make conclusions about the current level and projected national economic systems' development. Practical significance. The adapted and regulated procedure of harmonic and spectral analysis of socio-economic systems' oscillating processes became the basis for forecasting the level, rates and proportions of national economic systems development.

Keywords: oscillating development processes, forecasting economic dynamics, harmonic and spectral analysis, crucial harmonics, economic cycles 
Irina S. Kladchenko - Assistant of Department of Enterprise Economics, SHEI "Donetsk National Technical University"

E-mail: iryna.kladchenko@donntu.edu.ua

\section{ПРОГНОЗИРОВАНИЕ ТРАЕКТОРИИ НАЦИОНАЛЬНОГО ЭКОНОМИЧЕСКОГО РАЗВИТИЯ МЕТОДАМИ СПЕКТРАЛЬНОГО И ГАРМОНИЧЕСКОГО АНАЛИЗА}

Цель. Углубление и совершенствование методического инструментария прогнозирования поведения национальных экономик в контексте повышения обоснованности и результативности государственных стратегий развития национальной экономической системы в условиях высокой волатильности, отсутствия трендоустойчивости, нестационарности динамики внешних и внутренних социально-экономических процессов путем имплементации междисциплинарных методов гармонического и спектрального анализа сложных динамических систем естественного происхождения и их адаптации $к$ спеиифике функционирования $u$ развития социально-экономических систем. Методика. Актуализация места прогнозирования как важного самостоятельного этапа в процессе аналитического оценивания сбалансированности развития выполнено на основе структурирования, разделения на этапы, систематизации, группирования. Процесс обоснования междисииплинарного подхода для прогнозирования развития национальной экономической системы осуществлено методами анализа и синтеза, сравнения и практической апробации. Определение структурных закономерностей экономической динамики и прогнозирования траектории развития национальной экономики выполнено методами гармонического и спектрального анализа колебательных прочессов динамических систем. Результаты. Сконцентрировано внимание на специифических чертах временных рядов макроэкономической динамики как основы прогнозирования развития национальных экономик, а именно их короткой продолжительности, нестационарности, апериодичности, полигармоничности и их влиянии на формирование адекватного методического обеспечения прогнозирования. Обоснована возможность $и$ эффективность использования методов спектрального и гармонического анализа колебательных процессов развития национальной экономической системь. Сформирован гармоничную модель траектории развития экономики Украины в течение $1991-2020$ г2., которая позволила проанализировать колеблющуюся составляюшую динамики макроэкономических индикаторов на основе фактических данных, которые содержат всю первоначальную информацию, содержащую временной ряд. С помощью выделения экономических циклов, их амплитудно-частотных характеристик охарактеризована современная фаза развития украинской экономики. На основе разработанной модели экономической динамики по показателю темпов изменения ВВП выполнено прогнозирование $u$ определены краткосрочные, среднесрочные $u$ долгосрочные тенденции развития экономики Украины. Научная новизна. Углубление теоретикометодического инструментария прогнозирования тенденщий развития национальных экономик на основе гармонического и спектрального анализа позволило сформировать структурный подход $\kappa$ анализу экономической динамики в контексте выделения в ее составе определяюших гармоник и на основе их характеристик делать выводы об уровне и ожидаемой тенденции развития национальных экономических систем. Практическая значимость. Адаптированная и регламентированная процедура гармонического $и$ спектрального анализа колебательных процессов социально-экономических систем стала основой для прогнозирования уровня темпов и пропорций развития национальных экономических систем.

Ключевые слова: колебательные прочессы развития, прогнозирование экономической динамики, гармонический и спектральный анализ, критические гармоники, экономические циильь

Кладченко Ирина Сергеевна - ассистент кафедры экономики предприятия, ГВУЗ "Донецкий национальный технический университет", E-mail: iryna.kladchenko@donntu.edu.ua 